\title{
HUBUNGAN PENDIDIKAN IBU DENGAN STATUS GIZI ANAK USIA 3-5 TAHUN DI DESA SINDANGSARI KECAMATAN CIKONENG KABUPATEN CIAMIS TAHUN 2019
}

\author{
Ana Samiatul Milah ${ }^{1}$, Ade Zaqiah ${ }^{2}$ \\ ${ }^{1,2}$ Jurusan Keperawatan Fakultas Ilmu Kesehatan Universitas Galuh Ciamis \\ Corresponding Email : anamilah.fikesunigal82@gmail.com \\ (Diterima 17-11-2019; disetujui 24-11-2019; dipublish 27-11-2019)
}

\begin{abstract}
Abstrak
Masalah gizi/ nutrisi terjadi di setiap siklus kehidupan dan sepanjang daur kehidupan perempuan, dimulai sejak dalam kandungan (janin), bayi, anak, dewasa dan usia lanjut. Periode dua tahun pertama kehidupan merupakan masa kritis, karena pada masa ini terjadi pertumbuhan dan perkembangan yang sangat pesat. Gangguan gizi yang terjadi pada periode ini bersifat permanen, tidak dapat dipulihkan walaupun kebutuhan gizi pada masa selanjutnya terpenuhi. Data yang diperoleh dari Puskesmas Cikoneng Kecamatan Cikoneng Kabupaten Ciamis pada tahun 2017 pada bulan Januari status gizi balita didapatkan, tetapi penderita gizi balita kurang seluruhnya berjumlah 29 Anak. Kemudian ditahun 2018 mengalami peningkatanya itu berjumlah 46 anak yang terdiri dari gizi kurang 42 anak dan gizi buruk 4 anak dari 789 anak yang dapat diukur dan pada tahun 2019 sebanyak 213 orang. Metode yang digunakan dalam penelitian ini adalah metode penelitian deskriptif analitik. Populasi dalam penelitian ini adalah seluruh ibu dan balita usia 3-5 tahun di Desa Sindangsari Kecamatan Cikoneng Kabupaten Ciamis berjumlah 213 orang. Teknik pengambilan sampel yang digunakan adalah dengan menggunakan teknik random sampling.Hasil penelitian ini adalah hasil penelitian dari 68 responden, pendidikan ibu dalam kategori pendidikan menengah dengan status gizi baik pada anak yaitu sebanyak 15 (62.5\%) responden. Hasil uji hipotesis dengan menggunakan chi square didapat $p$ value sebesar 0.014 lebih kecil dari alpha 0.05. Dari hasil penelitian ini dapat disimpulkan bahwa ada hubungan antara pendidikan ibu dengan status gizi anak usia 3-5 tahun di Desa Sindangsari Kecamatan Cikoneng Kabupaten Ciamis dengan $p$-value sebesar 0.014 lebih kecil dari alpha $=0.05$. Dari hasil penelitian diharapkan dapat memberikan kontribusi secara ilmiah bagi peningkatan ilmu pengetahuan yang terkait dengan masalah tumbuh kembang anak serta dapat di jadikan sebagai informasi untuk menambah pengetahuan tentang pentingnya tumbuh kembang anak bagi masyarakat dalam rangka meningkatkan kesehatan dan kesejahteraan Ibu dan anak,dapat juga untuk anak menjadi sehat di lihat dari asupan nutrisi,status kesehatan baik dari status gizi dan Pemerisaan kesehatan,salah satu langgkah dalam upaya dengan melakukan penyuluhan gizi pada masyarakat khususnya ibu yang mempunyai anak balita pada usia 3-5 tahun.
\end{abstract}

Kata Kunci $\quad$ : Pendidikan, Kesehatn, Status Gizi Anak

\section{Abstract}

Nutrition / nutrition problems occur in every life cycle and throughout the life cycle of women, starting from the womb (fetus), infants, children, adults and old age. The period of the first two years of life is a critical period, because during this period there was very rapid growth and development. Nutritional disorders that occur in this period are permanent, cannot be recovered even though nutritional needs in the next period are met. Data obtained 
from the Cikoneng Health Center in Cikoneng Sub-district of Ciamis District in 2017 in January the nutritional status of children under five was obtained, but the total number of malnourished sufferers was 29 children. Then in 2018 experienced an increase of 46 children consisting of 42 undernourished children and 4 malnourished children out of 789 children who could be measured and in 2019 there were 213 people. The method used in this research is analytic descriptive research method. The population in this study were all mothers and toddlers aged 3-5 years in Sindangsari Village, Cikoneng District, Ciamis Regency amounted to 213 people. The sampling technique used was using random sampling technique. The results of this study were the results of research of 68 respondents, mother's education in the secondary education category with good nutritional status in children as many as 15 (62.5\%) respondents. Hypothesis test results using chi square obtained p value of 0.014 smaller than alpha 0.05. From the results of this study it can be concluded that there is a relationship between maternal education and nutritional status of children aged 3-5 years in Sindangsari Village, Cikoneng District, Ciamis Regency with a p-value of 0.014 smaller than alpha $=$ 0.05. The results of the study are expected to contribute scientifically to the improvement of knowledge related to child growth and development problems and can be used as information to increase knowledge about the importance of child development for the community in order to improve the health and welfare of mothers and children, can also be for children to be healthy in terms of nutritional intake, good health status from nutritional status and health assessment, one of the steps in efforts to conduct nutrition counseling to the community, especially mothers who have children under five at the age of 3-5 years.

Keywords: Education, Health, Child Nutritional Status 
PENDAHULUAN

Masalah gizi terjadi di setiap siklus kehidupan, dimulai sejak dalam kandungan (janin), bayi, anak, dewasa dan usia lanjut. Periode dua tahun pertama kehidupan merupakan masa kritis, karena pada masa ini terjadi pertumbuhan dan perkembangan yang sangat pesat. Gangguan gizi yang terjadi pada periode ini bersifat permanen, tidak dapat dipulihkan walaupun kebutuhan gizi pada masa selanjutnya terpenuhi ${ }^{1}$.

Tujuan utama Pembangunan Nasional menuju Indonesia Sehat 2017 adalah meningkatkan kesadaran, kemauan dan kemampuan hidup sehat bagi setiap individu untuk mewujudkan derajat kesehatan masyarakat yang optimal melalui terciptanya masyarakat, bangsa dan negara Indonesia yang ditandai dengan penduduknya hidup dalam lingkungan yang sehat, memiliki kemampuan untuk menjangkau pelayanan kesehatan yang bermutu secara adil dan merata.

Departemen Kesehatan RI selalu berupaya untuk melakukan peningkatan derajat kesehatan masyarakat. Pemerintah (melalui Depkes RI) berkewajiban untuk selalu mensejahterakan rakyat melalui peningkatan derajat kesehatan masyarakat. Salah satu upaya peningkatan derajat kesehatan adalah perbaikan gizi masyarakat. Gizi yang seimbang dapat meningkatkan ketahanan tubuh, dapat meningkatkan kecerdasan dan menjadikan pertumbuhan yang normal.

Namun sebaliknya gizi yang tidak seimbang menimbulkan masalah yang sangat sulit sekali ditanggulangi oleh Indonesia. Masalah gizi yang tidak seimbang itu adalah Kurang Energi Protein (KEP), Kurang Vitamin A (KVA).

Khusus untuk masalah Kurang Energi Protein (KEP) atau biasa dikenal dengan gizi kurang atau yang sering ditemukan secara mendadak adalah gizi buruk terutama pada anak balita, masih merupakan masalah yang sangat sulit sekali ditanggulangi oleh pemerintah. Penyebab gizi buruk itu sendiri pada dasarnya sangat sederhana yaitu kurangnya intake (konsumsi) makanan terhadap kebutuhan makan seseorang, namun tidak demikian bagi pemerintah dan masyarakat karena masalah gizi buruk adalah masalah ketersediaan pangan ditingkat rumah tangga. Namun anehnya di daerah-daerah yang telah swasembada pangan bahkan telah terdistribusi merata sampai ke tingkat rumah tangga (misalnya program raskin), masih sering ditemukan kasus gizi buruk, padahal sebelum gizi buruk ini terjadi, telah melewati beberapa tahapan yang dimulai dari penurunan berat badan dari berat badan ideal seorang anak sampai akhirnya terlihat anak tersebut sangat buruk (gizi buruk). Jadi masalah sebenarnya adalah masyarakat atau keluarga anak belum mengatahui cara menilai atau juga belum mengetahui pola pertumbuhan berat badan anak ${ }^{2}$.

Data tahun 2018 memperlihatkan 4 juta balita Indonesia kekurangan gizi. Sejumlah 700 ribu diantaranya mengalami gizi buruk. Sementara yang mendapat program makanan tambahan hanya 39 ribu anak. Ditinjau dari tinggi badan, sebanyak 25,8 persen anak Indonesia pendek (SKRT 2018). Ukuran tubuh yang pendek ini merupakan tanda kurang gizi yang berkepanjangan.

Lebih jauh, kekurangan gizi dapat mempengaruhi perkembangan otak anak. Padahal, otak tumbuh selama masa balita. Fase cepat tumbuh otak berlangsung mulai dari janin usia 30 minggu sampai bayi 18 bulan. (Prof. Dr. Ir. Ali Khomsan, MS)

Menurut Susenas tahun 2018 di Indonesia didapatkan $8,10 \%$ anak atau sekitar 1,7 juta anak menderita KEP tingkat berat (Gizi Buruk) menurut Berat Badan terhadap umur (BB/Umur). Sekitar $10 \%$ dari 1,7 juta balita ini (sekitar 170.000 balita) menderita gizi buruk tingkat berat seperti Marasmus, Kwashiorkor atau bentuk kombinasi Marasmik Kwashiorkor. Data jumlah balita gizi buruk tingkat berat yang tercatat di Depkes sampai akhir tahun 
2018 sekitar 24.000 anak (berdasarkan laporan Kejadian Luar Biasa (KLB) ${ }^{3}$.

Data yang diperoleh di Kabupaten Ciamis pada tahun 2018 jumlah penderita gizi buruk ditemukan sebanyak $686(84,3 \%)$ orang dari 1.851 anak, dan gizi kurang sebanyak $1.536(0,16 \%)$ orang dari 9.396 anak. Kemudian pada tahun 2018 jumlah penderita gizi buruk ditemukan sebanyak $641(2,32 \%)$ orang dari 29.454 anak, dan gizi kurang sebanyak $5.274(19,07 \%)$ dari 34.673 anak. Selanjutnya pada tahun 2016 penderita gizi buruk sebanyak $877(2,53 \%)$ dari 29.454 anak, dan gizi kurang sebanyak 5.954 (17,2\%) dari 34.673 anak. Sedangkan pada tahun 2013 penderita gizi buruk ditemukan sebanyak $461 \quad(1,6 \%)$ dari 29.454 anak dan gizi kurang sebanyak $4.241(14,4 \%)$ dari 34.673 anak.

Data yang diperoleh dari Puskesmas Cikoneng Kecamatan Cikoneng Kabupaten Ciamis pada tahun 2019 penderita gizi anka kurang seluruhnya berjumlah 68 anak. Kemudian ditahun 2019 mengalami peningkatan yaitu berjumlah 46 anak yang terdiri dari gizi kurang 42 angka dan gizi buruk 4 anak dari 789 anak yang dapat diukur. Berdasarkan Studi pendahuluan yang dilakukan di Desa Sindangsari Kecamatan Cikoneng Kabupaten Ciamis, bahwa dari 213 anka Usia 3-5 Tahun terdapat 1 Balita menderita Gisi Buruk.

Dari data diatas penderita gizi balita di Bawah garis merah (BGM) dari tahun 2017 sampai 2018 mengalami peningkatan, ini menunjukkan tujuan akan menurunkan angka balita di bawah garis merah belum tercapai sehingga membutuhkan petugas kesehatan khususnya bagi Puskesmas Sindangsari untuk meningkatkan kinerjanya. Untuk meminimalkan jumlah penderita gizi di bawah garis merah (BGM) sehingga pertumbuhan dan perkembangan balita dapat terpenuhi sesuai dengan umurnya, tentu sangat diharapkan peran serta kader kesehatan yang secara aktif melakukan penyuluhan kesehatan di tengah masyarakat.
Penyebab utama masalah gizi di Indonesia yaitu kemiskinan kemudian penyebab keduanya yaitu anak sering sakit sedangkan penyebab lainnya yaitu pola makan yang salah, kurangnya pengetahuan orang tua tentang gizi yang dilatarbelakangi oleh pendidikan orang tua, kurangnya fasilitas pelayanan kesehatan dan kelainan struktur bawaan anak. Salah satu upaya cukup penting terhadap peningkatan kualitas sumber daya manusia adalah upaya peningkatan gizi balita. Gizi anak merupakan salah satu faktor yang menentukan kualitas hidup seseorang dimasa mendatang. Angka kematian yang tinggi pada bayi, anak balita, ibu melahirkan dan menurunnya daya kerja fisik, terganggunya perkembangan mental dan kecerdasan jika ditelusuri adalah akibat langsung maupun tidak langsung dari kekurangan gizi ${ }^{4}$.

Pengetahuan di latarbelakangi oleh pendidikan, pndidikan yang lebih tinggi akan mempengaruhi pengetahuan seseorang. Pengetahuan ibu tentang makanan yang mengandung gizi, memilih makanan yang sehat, menghindari makanan yang sudah banyak diproses sangat diperlukan guna mencegah adanya gangguan status gizi (gizi lebih/gizi kurang. Pengalamam ibu yang kurang disebabkan oleh pendidikan yang rendah. Untuk meningkatkan pengetahuan ibu diperlukan pendidikan kesehatan dengan melalui komunikasi ataupun dinamika kelompok ${ }^{5}$.

Pendidikan yang rendah mempunyai resiko untuk terjadinya gizi kurang dibandingkan orang tua yang berpendidikan tinggi. Ibu dengan berpendidikan rendah maka pengetahuan tentang cara pemberian makanan pada balita pun kurang baik sehingga berpotensi menimbulkan malnutrisi ${ }^{6}$.

Anak yang mengalami masalah gizi khususnya gizi kurang dan gizi buruk mempunyai resiko untuk mengalami hambatan pertumbuhan baik fisik maupun mental. Lebih dari itu, akibat status gizi yang rendah/kurang bahkan buruk yang 
telah dipaparkan sebelumnya, balita juga rentang mengalami penyakit infeksi sehingga resiko akan kematian anak dapat saja terjadi.

\section{METODE PENELITIAN}

Metode yang digunakan dalam penelitian ini adalah dengan pendekatan cross sectional yaitu dengan melakukan pengukuran atau pengamatan pada saat bersamaan (sekali waktu) ${ }^{7}$. Dalam penelitian ini akan dibahas mengenai hubungan pendidikan ibu dengan status gizi anak usia 3-5 tahun di Desa Sindangsari Kecamatan Cikoneng Kabupaten Ciamis Periode Februari-Juni Tahun 2019. Populasi dalam penelitian ini adalah seluruh ibu dan anak usia 3-5 tahun di Desa Sindangsari Kecamatan Cikoneng Kabupaten Ciamis berjumlah 213 orang. Sampel dalam penelitian ini yaitu seluruh ibu dan anak usia 3-5 tahun di Desa Sindangsari Kecamatan Cikoneng Kabupaten Ciamis Tahun 2019. Penelitian ini akan dilaksanakan di Desa Sindangsari Kecamatan Cikoneng Kabupaten Ciamis Tahun 2019. Instrumen penelitian ini dilakukan menggunakan alat ukur kuesioner tentang pendidikan ibu dan KMS untuk penilaian status gizi anak umur 3-5 tahun. Kuesioner sebelumnya telah dibuat oleh peneliti dengan mengacu pada kepustakaan yang terdiri dari beberapa pertanyaan.

\section{HASIL PENELITIAN \\ Karakteristik Responden}

Dalam penelititan ini untuk mengetahui Hubungan karakteristik responden akan disajikan berdasarkan usia, dan pekerjaan yang akan disajikan dalam bentuk tabel distribusi frekuensi. Hubungan Ibu yang memiliki balita menurut usia di Desa Sindangsari Kecamatan Cikoneng Kabupaten Ciamis dapat dilihat pada tabel 1 berikut ini:

\begin{tabular}{|c|l|c|c|}
\hline No & Pekerjaan Ibu & Frekuensi & Prosentase \\
\hline 1 & IRT & 18 & $26.5 \%$ \\
\hline 2 & Petani & 26 & $38.2 \%$ \\
\hline 3 & Wiraswasta & 68 & $22.1 \%$ \\
\hline 4 & PNS & 9 & $13.2 \%$ \\
\hline & Jumlah & $\mathbf{6 8}$ & $\mathbf{1 0 0 . 0 \%}$ \\
\hline
\end{tabular}

Tabel 2

Distribusi Frekuensi Ibu Menurut Usia di Desa Sindangsari Kecamatan Cikoneng Kabupaten Ciamis Tahun 2019

\begin{tabular}{|c|c|c|c|}
\hline No & Usia Ibu & Frekuensi & Prosentase \\
\hline 1 & $\leq 20$ Tahun & 6 & $8.8 \%$ \\
\hline 2 & $21-30$ Tahun & 46 & $67.7 \%$ \\
\hline 3 & $31-40$ Tahun & 13 & $19.1 \%$ \\
\hline 4 & $>40$ Tahun & 3 & $4.4 \%$ \\
\hline & Jumlah & $\mathbf{6 8}$ & $\mathbf{1 0 0 . 0} \%$ \\
\hline
\end{tabular}

Sumber : Data Primer Penelitian Tahun 2019

Berdasarkan hasil penelitian pada tabel 4.1 diketahui bahwa dari 68 responden di Desa Sindangsari Kecamatan Cikoneng Kabupaten Ciamis Tahun 2019, paling banyak berusia 21 - 30 tahun yaitu sebanyak 46 responden $(67.7 \%), 31-40$ tahun sebanyak 13 responden $(19.1 \%),<=$ 20 tahun sebanyak 6 responden $(8.8 \%)$, dan > 40 tahun sebanyak 3 responden (4.4\%).

\section{Hubungan Ibu Yang Memiliki Anak Menurut Pekerjaan}

Berdasarkan hasil penelitian diketahui bahwa dari 68 responden di Desa Sindangsari Kecamatan Cikoneng Kabupaten Ciamis paling banyak bekerja sebagai petani yaitu sebanyak 26 responden (38.2\%), IRT sebanyak 18 responden $(26.5 \%)$, wiraswasta sebanyak 68 responden $(22.1 \%)$, dan PNS sebanyak 9 responden $(13.2 \%)$. 


\begin{tabular}{|c|c|c|c|c|c|c|c|c|c|c|c|}
\hline \multirow{3}{*}{$\begin{array}{c}\text { Pendidik } \\
\text { an Ibu }\end{array}$} & \multicolumn{8}{|c|}{ Status Gizi Anak } & \multirow{2}{*}{\multicolumn{2}{|c|}{ Total }} & \multirow{3}{*}{$\begin{array}{c}p- \\
\text { valu } \\
e\end{array}$} \\
\hline & \multicolumn{2}{|c|}{$\begin{array}{l}\text { Gizi } \\
\text { Baik }\end{array}$} & \multicolumn{2}{|c|}{$\begin{array}{c}\text { Gizi } \\
\text { Sedang }\end{array}$} & \multicolumn{2}{|c|}{$\begin{array}{c}\text { Gizi } \\
\text { Kura } \\
\text { ng }\end{array}$} & \multicolumn{2}{|c|}{$\begin{array}{c}\text { Gizi } \\
\text { Buruk }\end{array}$} & & & \\
\hline & $\mathbf{F}$ & $\%$ & $\mathbf{F}$ & $\%$ & $\mathbf{F}$ & $\%$ & $\mathbf{F}$ & $\%$ & $\mathbf{F}$ & $\%$ & \\
\hline $\begin{array}{l}\text { Pend. } \\
\text { Dasar }\end{array}$ & $\begin{array}{l}6 \\
8\end{array}$ & $\begin{array}{l}42 \\
.9\end{array}$ & $\begin{array}{l}1 \\
1\end{array}$ & $\begin{array}{l}31 \\
.4\end{array}$ & 7 & $\begin{array}{l}20 \\
.0\end{array}$ & 2 & $\begin{array}{l}5 . \\
7\end{array}$ & 35 & $\begin{array}{l}100 . \\
0\end{array}$ & \\
\hline $\begin{array}{l}\text { Pend. } \\
\text { Menenga } \\
\text { h }\end{array}$ & $\begin{array}{l}6 \\
8\end{array}$ & $\begin{array}{l}62 \\
.5\end{array}$ & 9 & $\begin{array}{l}37 \\
.5\end{array}$ & 0 & $\begin{array}{l}0 . \\
0\end{array}$ & 0 & $\begin{array}{l}0 . \\
0\end{array}$ & 24 & $\begin{array}{l}100 . \\
0\end{array}$ & 0.01 \\
\hline $\begin{array}{l}\text { Pend. } \\
\text { Tinggi }\end{array}$ & 9 & $\begin{array}{l}10 \\
0\end{array}$ & 0 & $\begin{array}{l}0 . \\
0\end{array}$ & 0 & $\begin{array}{l}0 . \\
0\end{array}$ & 0 & $\begin{array}{l}0 . \\
0\end{array}$ & 9 & $\begin{array}{l}100 . \\
0\end{array}$ & \\
\hline Jumlah & $\begin{array}{l}3 \\
9 \\
\end{array}$ & $\begin{array}{l}57 \\
.4\end{array}$ & $\begin{array}{l}2 \\
0\end{array}$ & $\begin{array}{l}29 \\
.4\end{array}$ & 7 & $\begin{array}{l}10 \\
.3\end{array}$ & 2 & $\begin{array}{l}2 . \\
9\end{array}$ & 68 & $\begin{array}{l}100 . \\
0\end{array}$ & \\
\hline
\end{tabular}

Sumber : Data Primer Penelitian 2019.

Berdasarkan hasil penelitian pada tabel 1 diketahui bahwa dari 68 responden, pendidikan ibu dalam kategori pendidikan menengah dengan status gizi baik pada balita yaitu sebanyak 68 (62.5\%) responden. Hasil uji hipotesis dengan menggunakan chi square didapat $p$ value sebesar 0.014 lebih kecil dari alpha 0.05. Sehingga keputusannya adalah ada hubungan antara pendidikan ibu dengan status gizi anak usia 3-5 tahun di Desa Sindangsari Kecamatan Cikoneng Kabupaten Ciamis Tahun 2019.

\section{PEMBAHASAN}

\section{Pendidikan Ibu}

Hasil penelitian mengenai pendidikan ibu di Desa Sindangsari Kecamatan Cikoneng Kabupaten Ciamis menunjukan bahwa dari 68 responden sebagian besar pendidikan ibu ada dalam kategori pendidikan dasar yaitu sebanyak 35 responden (51.5\%). Tingkat pendidikan seseorang atau suatu kelompok akan mempengaruhi tingkat pengetahuan yang dimiliki. Pendidikan adalah suatu usaha untuk mengembangkan kepribadian dan kemampuan di dalam dan di luar sekolah dan berlangsung seumur hidup. Pendidikan mempengaruhi proses belajar, makin tinggi pendidikan seseorang makin mudah orang tersebut untuk menerima informasi. Dengan pendidikan tinggi maka seseorang akan cenderung untuk mendapatkan informasi, baik dari orang lain maupun dari media massa. Semakin banyak informasi yang masuk semakin banyak pula pengetahuan yang didapat tentang kesehatan.
Pengetahuan sangat erat kaitannya dengan pendidikan dimana diharapkan seseorang dengan pendidikan tinggi, maka orang tersebut akan semakin luas pula pengetahuannya. Namun perlu ditekankan bahwa seorang yang berpendidikan rendah tidak berarti mutlak berpengetahuan rendah pula. Peningkatan pengetahuan tidak mutlak diperoleh di pendidikan formal, akan tetapi juga dapat diperoleh pada pendidikan non formal. Pengetahuan seseorang tentang sesuatu obyek juga mengandung dua aspek yaitu aspek positif dan negatif. Kedua aspek inilah yang akhirnya akan menentukan sikap seseorang terhadap obyek tertentu. Semakin banyak aspek positif dari obyek yang diketahui, akan menumbuhkan sikap makin positif terhadap obyek tersebut.

Pengetahuan seseorang dapat diperoleh dari pengalaman pribadi dan pihak lain seperti orang tua, petugas, teman, buku dan komunikasi lainnya. Selain itu, faktor yang mempunyai korelasi positif dengan tingkat pengetahuan adalah variabel pendidikan ${ }^{8}$.

Pengetahuan di latarbelakangi oleh pendidikan, pendidikan yang lebih tinggi akan mempengaruhi pengetahuan seseorang. Pengetahuan ibu tentang makanan yang mengandung gizi, memilih makanan yang sehat, menghindari makanan yang sudah banyak diproses sangat diperlukan guna mencegah adanya gangguan status gizi (gizi lebih/gizi kurang). Pengalaman ibu yang kurang disebabkan oleh pendidikan yang rendah. Untuk meningkatkan pengetahuan ibu diperlukan pendidikan kesehatan dengan melalui komunikasi ataupun dinamika kelompok ${ }^{5}$.

\section{Status Gizi Anak}

Hasil penelitian mengenai status gizi anak di Desa Sindangsari Kecamatan Cikoneng Kabupaten Ciamis tahun 2019 menunjukan bahwa dari 68 responden, sebagian besar status gizi balita termasuk dalam kategori gizi baik sebanyak 39 responden (57.4\%). Berdasarkan hasil penelitian, status gizi anak yang sebagian 
besar berada pada kategori gizi baik, Hal ini dapat dipengaruhi oleh faktor makanan yang dikonsumsi oleh anak. Hal ini sejalan dengan apa yang dikemukakan oleh Supariasa, (2006) peran makanan bagi anak. Makanan sebagai sumber zat gizi. Didalam makanan terdapat enam jenis zat gizi, yaitu karbohidrat, lemak, protein, vitamin, mineral, dan air.

Status gizi adalah keadaan kesehatan individu-individu atau kelompokkelompok yang ditentukan oleh derajat kebutuhan fisik akan energi dan zat-zat gizi lain yang diperoleh dari pangan dan makanan yang dampak fisiknya diukur secara antropometri. Status gizi adalah ekspresi dari keadaan keseimbangan dalam bentuk variabel tertentu, atau perwujudan dari nutrisi dalam bentuk variabel tertentu. Contoh : KEP merupakan keadaan tidak seimbangnya pemasukan dan pengeluaran energi dan protein di dalam tubuh seseorang ${ }^{4}$.

Status gizi optimal adalah keseimbangan antara asupan zat gizi dengan kebutuhan zat gizi. Dengan demikian asupan zat gizi mempengaruhi status gizi seseorang. Status gizi adalah keadaan kesehatan individu yang ditentukan oleh keseimbangan antara asupan zat gizi dengan kebutuhan zat gizi ${ }^{9}$.

Berat badan adalah salah satu parameter yang memberikan Hubungan massa tubuh. Massa tubuh sangat sensitif terhadap perubahan-perubahan yang mendadak, misalnya karena terserang penyakit infeksi, menurunnya nafsu makan atau menurunnya jumlah makanan yang dikonsumsi. Dalam keadaan normal, dimana keadaan kesehatan baik dan keseimbangan antara konsumsi dan kebutuhan zat gizi terjamin, maka berat badan berkembang mengikuti pertambahan umur. Sebaliknya dalam keadaan yang abnormal, terdapat 2 kemungkinan perkembangan berat badan, yaitu dapat berkembang cepat atau lebih lambat dari keadaan normal. Berdasarkan karakteristik berat badan ini, maka indeks berat badan menurut umur digunakan sebagai salah satu cara pengukuran status gizi. Mengingat karakteristik berat badan yang labil, maka indeks Berat Badan/Umur $(\mathrm{BB} / \mathrm{U})$ lebih menggambarkan status gizi seseorang saat ini ${ }^{5}$.

Faktor yang mempengaruhi status gizi meliputi Faktor Internal diantanya: a) status kesehatan, b) umur, c) jenis kelamin, d) ukuran tubuh, faktor Eksternal diantaranya: a) pendidikan, b) pengetahuan c) infeksi d) pendapatan.

Anak anak merupakan kelompok yang menunjukkan pertumbuhan pesat, sehingga memerlukan zat-zat gizi yang tinggi setiap kilogram berat badannya. Anak anak ini justru merupakan kelompok umur yang paling sering menderita akibat kekurangan gizi (KKP). Beberapa kondisi dan anggapan orang tua dan masyarakat justru merugikan penyediaan makan bagi kelompok anak ini :

1. Anak anak masih dalam periode transisi dari makanan bayi ke makanan orang dewasa, jadi masih memerlukan adaptasi.

2. Anak anak dianggap kelompok umur yang paling belum berguna bagi keluarga, baik tenaga maupun kesanggupan kerja penambah keuangan. Anak itu sudah tidak begitu diperhatikan dan pengurusannya sering diserahkan kepada saudaranya yang lebih tua, tetapi sering belum cukup umur untuk mempunyai pengalaman dan ketrampilan untuk mengurus anak dengan baik.

3. Ibu sering sudah mempunyai anak kecil lagi atau sudah bekerja penuh sehingga tidak lagi dapat memberikan perhatian kepada anak anak apalagi mengurusnya.

4. Anak anak masih belum dapat mengurus sendiri dengan baik, dan belum dapat berusaha mendapatkan sendiri apa yang diperlukannya untuk makanannya.

5. Anak anak mulai turun ke tanah dan berkenalan dengan berbagai kondisi yang memberikan infeksi atau penyakit lain, padahal tubuhnya belum cukup 
mempunyai immunitas atau daya tahan untuk melawan bahaya kepada dirinya (Soediatma, 2018).

\section{Hubungan Antara Pendidikan dengan Status Gizi}

Berdasarkan hasil penelitian dari 68 responden, pendidikan ibu dalam kategori pendidikan menengah dengan status gizi baik pada balita yaitu sebanyak 68 (62.5\%) responden. Hasil uji hipotesis dengan menggunakan chi square didapat $p$ value sebesar 0.014 lebih kecil dari alpha 0.05. Sehingga hasil penelitian menunjukan bahwa ada hubungan pendidikan ibu dengan status gizi anak usia 3-5 tahun di Desa Sindangsari Kecamatan Cikoneng Kabupaten Ciamis tahun 2019.

Hal ini sejalan dengan teori yang dikemukakan oleh Acmadi, (2018) bahwa secara tidak langsung masalah gizi pada anak salah satunya dipengaruhi oleh pendidikan, karena sangat mempengaruhi terhadap pengetahuan, tentang gizi khususnya.

Pendidikan yang rendah mempunyai resiko untuk terjadinya gizi kurang dibandingkan orang tua yang berpendidikan tinggi. Ibu dengan berpendidikan rendah maka pengetahuan tentang cara pemberian makanan pada anak pun kurang baik sehingga berpotensi menimbulkan malnutrisi ${ }^{9}$.

Anak yang mengalami masalah gizi khususnya gizi kurang dan gizi buruk mempunyai resiko untuk mengalami hambatan pertumbuhan baik fisik maupun mental. Lebih dari itu, akibat status gizi yang rendah/kurang bahkan buruk yang telah dipaparkan sebelumnya, balita juga rentang mengalami penyakit infeksi sehingga resiko akan kematian anak dapat saja terjadi ${ }^{10}$.

\section{SIMPULAN DAN SARAN}

Berdasarkan penelitian tentang hubungan antara pendidikan ibu dengan status gizi anak usia 3-5 tahun di Desa Sindangsari Kecamatan Cikoneng Kabupaten Ciamis Tahun 2019 dengan mengambil sampel 68 orang responden, maka penulis dapat menarik beberapa kesimpulan dari penelitian ini, yaitu :

1. Pendidikan ibu di Desa Sindangsari Kecamatan Cikoneng Kabupaten Ciamis Tahun 2019 sebagian besar dalam kategori pendidikan dasar yaitu (51.5\%).

2. Status gizi anak usia 3-5 tahun di Desa Sindangsari Kecamatan Cikoneng Kabupaten Ciamis Tahun 2019 sebagian besar status gizi balita dalam kategori gizi baik yaitu (57.4\%).

3. Ada hubungan antara pendidikan ibu dengan status gizi anak usia 3-5 tahun di Desa Sindangsari Kecamatan Cikoneng Kabupaten Ciamis Tahun 2019 dengan p-value sebesar 0.014 lebih kecil dari alpha $=0.05$.

\section{DAFTAR PUSTAKA}

1. Departemen Kesehatan RI.(2019). Stunting, Klasifikasi Status Gizi Anak Bawah Lima Tahun (BALILA), Jakarta : Direktorat Bina Kesehatan Masyarakat.

, (2017) Pedoman Pengelolaan Makanan pendamping Jakarta : Direktorat Bina Gizi Masyarakat.

2. Almatsier S. (2017). Prinsip Dasar Ilmu Gizi. Jakarta : Gramedia Pustaka Utama.

3. Arikunto S. (2015). Prosedur Penelitian Suatu Pendekatan Praktek. Rineka Cipta : Jakarta

4. Supriasa I Dewa Nyoman, dkk.(2015). Penilaian statis Gizi .Cet.I. Buku Kedokteran EGC : Jakarta.

5. Notoatmodjo, S (2015). Ilmu kesehatan Masyarakat. Jakarta: Penerbit PT . Rineka Cipta.

6. Soekidjo,(2015). Pendidikan dan Perilaku Kesehatan. Jakarta : Kedokteran EGC

7. Hidayat A. (2007). Pengantar Konsep Keperawatan anak. 
8. Baliwati, YF, Khomsan, A dan Dwiriani, CM. (2016). Pengantar Pandan dan Gizi, Cetakan II. Penebar Swadaya : Jakarta

9. Child Survival Collaboration and Resources , CM.(2016). Pengantar Ilmu gizi dan Pangan cetakan II, Jakarta : Penebar Swadaya.

10. CORE. (2015). Penanggulangan Stunting \&Health, Suatu Pendekatan Perubahan Perilaku\&Masalah gizi pada Masyarakat.Deterjemahkan oleh PCI Indonesia. Jakarta : 2016. 